American Journal of Environmental Sciences 5 (3): 223-229, 2009

ISSN 1553-345X

(C) 2009 Science Publications

\title{
Phenanthrene Contaminated Soil Biotreatment Using Slurry Phase Bioreactor
}

\author{
${ }^{1}$ M. Arbabi, ${ }^{1}$ M. Sadeghi and ${ }^{2}$ Ch. Anyakora \\ ${ }^{1}$ Department of Environmental Health, School of Health, Shahre-Kord \\ University of Medical Sciences, Shahre-kord, Iran \\ ${ }^{2}$ Department of Pharmaceutical Chemistry, University of Lagos, Nigeria
}

\begin{abstract}
Problem Statement: Polycyclic Aromatic Hydrocarbons (PAHs) are suspected toxins that accumulate in soils and sediments due to their insolubility in water and lack of volatility. Slurry-phase biological treatment is one of the innovative technologies that involve the controlled treatment of excavated soil in a bioreactor. Due to highly soil contamination from petroleum compounds in crude oil extraction and also oil refinery sites in Iran, this research was designed based on slurry phase biotreatment to find out a solution to decontamination of oil compounds polluted sites. Approach: Soil samples were collected from Tehran oil refinery site and Bushehr oil zones. Two compositions of soils (clay and silt) were selected for slurry biotreatment experiment. Soil samples were contaminated with three rates of phenanthrene (a 3 ring PAH), 100, 500 and $1000 \mathrm{mg} \mathrm{kg}^{-1}$ and mixed with distilled water in solid concentration of $30 \%$ by weight after washing out with strong solvent (hexane) and putting in to the oven. Bacterial consortium was revived in culture medium which consisted of Mineral Salt Medium (MSM) based on phenanthrene concentrations and ratio of C/N/P in the range of 100/10/2. Prepared soil samples were mixed with distilled water, nutrient and bacterial consortium together in the $250 \mathrm{~mL}$ glass Erlenmeyer and putted in the shaker incubator with $200 \mathrm{rpm}$ revolutions and $25^{\circ} \mathrm{C}$ for 7 weeks (45 days). Samples were analyzed for residual phenanthrene, bacterial population every week. For statistical analysis, general linear model with repeated measures (type III) analysis was applied. Results: The concentration of $100 \mathrm{mg} \mathrm{L}^{-1}$ of phenanthrene in clayey and silty soils reached to non detectable limit after 5 and 6 weeks, respectively. While concentration of $500 \mathrm{mg} \mathrm{L}^{-1}$ of phenanthrene both in clayey and silty soils reached to non detectable limit after 6 weeks. But concentration of $1000 \mathrm{mg} \mathrm{L}^{-1}$ both in clayey and silty soil samples has not met this limitation after 7 weeks. Due to presence of Pseudomonas strains in clayey soil samples and their ability in breaking down of benzene rings, the removal efficiency of phenanthrene in our slurry bioreactor in clayey soil was a little more than silty soil samples over time. There was a significance relationship between initial concentrations of phenanthrene and type of soil with time of biotreatment $(\mathrm{p}<0.001)$. Conclusion: Therefore, this technology may be applied to remediation of small foot print oil contaminated sites, e.g., gas station, oil extraction and refinery sites in Iran, in the case of urgency. Thus this study concludes that the remediation of phenanthrene with concentration up to $1000 \mathrm{mg} \mathrm{kg}^{-1}$ in the oil contaminated sites can be removed to the acceptable limits using slurry based system.
\end{abstract}

Key words: Polycyclic aromatic hydrocarbons, phenanthrene, PAH-contaminated soils, bioremediation, slurry phase bioreactor

\section{INTRODUCTION}

The fate of Polycyclic Aromatic Hydrocarbons (PAHs) in nature is of great environmental concern due to their toxic, mutagenic and carcinogenic properties. A major decomposition process of PAHs in the environment is microbial degradation ${ }^{[1,2]}$. PAHs are relatively persistent and recalcitrant in soils and are more difficult to be degraded than many other organic contaminants under natural conditions. There is an increasing interest in the cleaning of soil contaminated with organic compounds using bioremediation ${ }^{[3]}$.

Corresponding Author: M. Sadeghi, Department of Environmental Health, School of Health, Shahre-Kord, University of Medical Sciences (SKUMS), Shahre-kord, Iran 
Bioremediation has become an intensive area for research and, as result; rapid progress has been made in developing effective microbial bioremediation processes $^{[4]}$.

Individual microorganisms can metabolize only a limited range of hydrocarbon substrates, so assemblages of mixed populations with overall broad enzymatic capacities are required to bring the rate and extent of petroleum biodegradation further. Microbial populations that consist of strains that belong to various genera have been detected in petroleum-contaminated soil or water ${ }^{[5]}$. This strongly suggests that each strain or genera have their roles in the hydrocarbon transformation processes.

There are several treatment methods for PAHs contaminated soils including: incineration, fixation, thermal desorption, electro-kinetics, stabilization/solidification, solvent extraction wet oxidation, landfill and bioremediation. Bioremediation is the only practical consideration for complete degradation of organic contaminants ${ }^{[6]}$.

Aqueous slurry is created by combining soil, sediment, or sludge with water and other additives. The slurry is mixed to keep solids suspended and microorganisms in contact with the soil contaminants. Upon completion of the process, the slurry is dewatered and the treated soil is disposed off ${ }^{[7]}$.

In this study the focus was on phenanthrene soil remediation using slurry phase bioreactor in bench scale.

Background: Slurry-phase biological treatment is one the innovative technology that involves the controlled treatment of excavated soil in a bioreactor. The excavated soil is the first processed to physically separate stones and rubbles. The soil is then mixed with water to a predetermined concentration dependent upon the concentration of the contaminants, the rate of biodegradation and the physical nature of the soil. In some processes, concentrations of the contaminants occurring by pre-wash the soil. Then, clean sand may be discharged, leaving only contaminated fines and wash water for biotreatment. Typically, the slurry contains $10-40 \%$ solids by weight ${ }^{[7]}$. Slurry-phase bioreactors have been successfully used to remediate soils and sledges contaminated with explosives, petroleum hydrocarbons, petrochemicals, solvents, pesticides, wood preservatives and other organic chemicals. Slurry-phase bioreactors are favored over in situ biological techniques for heterogeneous soils, low permeability soils, areas where underlying groundwater would be difficult to capture, or when faster treatment time is required ${ }^{[7,8]}$.
In slurry phase bioreactor the contaminated soil is maintained in suspension in a reactor vessel and mixed with nutrients. If necessary, an acid or an alkali may be added to control $\mathrm{pH}$. Microorganisms also may be added if a suitable population is not present. When biodegradation is complete, the soil slurry is dewatered. Dewatering devices may include clarifiers, pressure filters, vacuum filters, sand drying beds, or centrifuges $^{[8]}$.

Treatment costs using slurry reactors range from $\$ 130-\$ 200$ per cubic meter. Costs ranging from $\$ 160$ $\$ 210$ per cubic meter are incurred when the slurrybioreactor off-gas has to be further treated because of the presence of volatile compounds ${ }^{[8]}$.

The following factors may limit the applicability and effectiveness of the process:

- Excavation of contaminated soils is required

- Sizing of materials prior to putting them into the reactor can be difficult and expensive; nonhomogeneous soils can create serious materials-handling problems

- Dewatering soil fines after treatment can be expensive

- An acceptable method for disposing of nonrecycled wastewaters is required

Slurry-phase bioreactors may be classified as shortto medium-term technologies. The duration of operation and maintenance is dependent on the following conditions:

- Concentration of contaminants

- Temperature of reactor

- Nutrient concentration

- Proper aeration (for aerobic bioreactors) ${ }^{[7]}$.

There are many environmental and health concerns when dealing with soil remediation. When soil is contaminated, it can not be used for any purposes, therefore the focus will be on ways to either remove or significantly reduce the amount of pollutant.

\section{MATERIALS AND METHODS}

Initial microbial isolation from contaminated soils was carried out using two oil contaminated soil samples which were collected from: (1) Tehran oil refinery site and (2) Bushehr oil zones. Samples were collected in the range of 3-4 $\mathrm{kg}$ from surface and $10 \mathrm{~cm}$ deep layer of petroleum contaminated soil. Prior to conducting any analysis on collected soils, the coarse pieces e.g., stones 
and debris were separated and the remaining were mixed well. The sub samples were kept cold $(3-5)^{\circ} \mathrm{C}$ for isolation of microorganisms. Microbial analyses were conducted within $24-48 \mathrm{~h}$ after sampling.

Soil sieve analysis carried out based on Unified Classification ${ }^{[9]}$. As the collected soil samples had a different composition, therefore, two soil compositions were selected for this research (i.e., clay and silt).

Initial mix consortiums isolation was done by mixing of $1 \mathrm{~g}$ soil with $10 \mathrm{~mL}$ of sterile $\mathrm{Na}_{2} \mathrm{P}_{2} \mathrm{O}_{7}$ solution with $0.025 \mathrm{M}\left(2.8 \mathrm{~g} \mathrm{~L}^{-1}\right)$ in $50 \mathrm{~mL}$ sterile Erlenmeyer which was mixed by a magnetic shaker for $2 \mathrm{~h}$ in $250 \mathrm{rpm}^{[10]}$. The soil particles were allowed to settle for $30 \mathrm{~min}$. The supernatant was diluted and plated on solid media. Microbial analysis was conducted both for fungi and bacteria.

After isolation and dilution of the contaminated specimens by $10^{-3}-10^{-5}$ times with sterile distilled water, they were plated on solid media, e.g., HPC (Heterotrophic Plate Count Agar) for bacterial analysis. Bacterial populations were detected as CFU (Colony Forming Unit) per gram of soil ${ }^{[11]}$. For identification and isolation of individual bacteria confirmative series tests and also Analytical Profile Index (API) kit tests were applied ${ }^{[12]}$. In this study phenanthrene $\left(\mathrm{C}_{14} \mathrm{H}_{10}\right)$ was selected as a PAH representative compound.

An HPLC with UV detector and PAH analytical column (Ultra Sep ES PAH QC Speica, $60 \times 2 \mathrm{mM} \mathrm{ID)}$ was employed for the analysis of residual phenanthrene in the contaminated soils ${ }^{[13]}$. Samples were extracted by acetonitrile in the Ultrasonic bath cleaner (modification of EPA methods of 3550, 8310 $)^{[14,15]}$.

Extraction of phenanthrene was conducted using ultrasonic machine. In this procedure $1 \mathrm{~g}$ of the contaminated soil was dried at air temperature and after sieving (using sieve with mesh \#50), was suspended in $10 \mathrm{~mL}$ of acetonitrile and extracted by ultrasonic bath at $40-50^{\circ} \mathrm{C}$ for $1 \mathrm{hr}$. Extracts were settled for $10 \mathrm{~min}$ and then centrifuged at $4500 \mathrm{rpm}$ for $15 \mathrm{~min}$. Elutes were filtered by $25 \mathrm{mM}$ in diameter, $2 \mu \mathrm{m}$ in pore size, PTFE membrane filter and submitted to HPLC-UVD analysis $^{[16]}$.

After enrichment of isolated bacteria consortium from two contaminated soil samples, two different mixed cultures were adapted to different concentrations of phenanthrene (e.g., 10, 50 and $100 \mathrm{mg} \mathrm{L}^{-1}$ ). Enrichment procedure was repeated for 8 times. After a period of two months, bacterial population numeration and phenanthrene residual concentrations were analyzed. Results showed a reasonable reduction of phenanthrene with bacterial population of $10^{5}-10^{8} \mathrm{CFU} \mathrm{g}^{-1}$ in all samples.

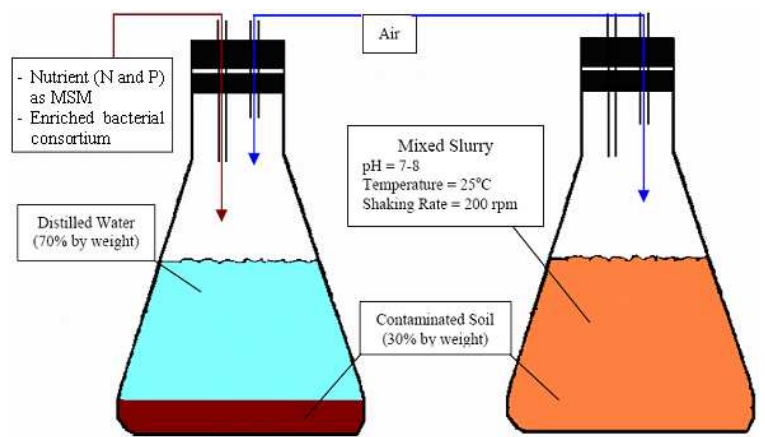

(a)

(b)

Fig. 1: Schematic of slurry phase bioreactor bench scale operation. (a): Before mixing; (b): After mixing

Experimental set-up: Two compositions of soils (clay and silt) were selected for slurry biotreatment experiment. After sieving the soil samples using sieve mesh \# 200, samples were washed out with strong solvent (hexane) and putted in to the oven in order to decontamination and clean up them completely. Soil samples were contaminated with three rates of phenanthrene, e.g., 100, 500 and $1000 \mathrm{mg} \mathrm{kg}^{-1}$ and mixed with distilled water in solids concentration of $30 \%$ by weight (30\% soil and $70 \%$ water). The consortium was revived in culture medium which consisted of Mineral Salt Medium (MSM) based on phenanthrene concentrations and ratio of $\mathrm{C} / \mathrm{N} / \mathrm{P}$ in the range of $100 / 10 / 2$ in the soil samples ${ }^{[17,18]}$. Beside of samples, blanks were prepared as a control of abiotic remediation. Soil samples were mixed with distilled water, nutrient and bacterial consortium together in the $250 \mathrm{~mL}$ glass Erlenmeyer and putted in the shaker incubator with $200 \mathrm{rpm}$ revolutions and $25^{\circ} \mathrm{C}$ for 7 weeks. Soil samples mixed with bacterial consortium based on derived indigenous bacterial population from same soils samples (i.e., bacterial consortium derived from Bushehr oil zone and Tehran refinery site were used for silty and clayey soil samples composition, respectively. Samples were collected for residual phenanthrene, bacterial population analysis every week. $\mathrm{pH}$ was adjusted at 7-8. Schematic of slurry bioreactor that was used in this study has showed in Fig. 1.

\section{RESULTS}

Initial soil samples characteristics are presented in Table 1. As shown in Table 1 and according to Unified Classification analysis, collected soil samples had a two different compositions, namely, SP-SC (clayey-sand, poorly graded sand-clay mixture) and SP-SM (siltysand, poorly graded sand-silt mixture) for Tehran refinery site and Bushehr oil zone respectively. 
Am. J. Environ. Sci., 5 (3): 223-229, 2009

Table 1: Initial characteristics of contaminated soil samples

\begin{tabular}{lll}
\hline Item & $\begin{array}{l}\text { Sample locations } \\
\text { tehran oil refinery }\end{array}$ & Bushehr oil zone \\
\hline $\begin{array}{l}\text { Initial phenanthrene rate } \\
\left(\mathrm{mg} \mathrm{kg}^{-1}\right)\end{array}$ & 60.000 & 12 \\
Microbial population (CFU) & $8.5 \times 10^{4}$ & $3 \times 10^{4}$ \\
Gravel (\%) & 0.000 & 1.240 \\
Sand (\%) & 90.000 & 91.860 \\
Silt $(\%)$ & -- & 6.900 \\
Clay (\%) & 10.000 & -- \\
Moisture $(\%)$ & 6.400 & 1.000 \\
pH & 6.800 & 7.100 \\
Organic carbon $(\%)$ & 7.890 & 7.312 \\
Bulk density (g mL $\left.{ }^{-1}\right)$ & 0.700 & 0.600 \\
Uniformity coefficient $(\mathrm{Uc})$ & 3.700 & 1.790 \\
Coefficient of curvature (Cc) & 0.490 & 0.730 \\
Effective size (mM) & 0.075 & 0.120 \\
Type of soil * & SP-SC & SP-SM \\
\hline
\end{tabular}

*SP-SC: Clayey-sand, poorly graded sand-clay mixture SP-SM: Siltysand. Poorly graded sand-silt mixture

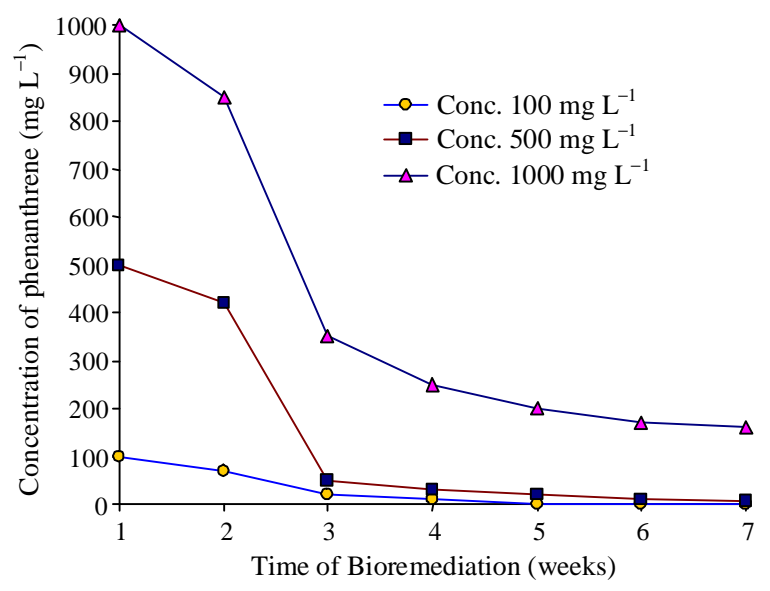

Fig. 2: Removal of phenanthrene in clayey contaminated soil over time

Removal of phenanthrene with different concentrations in clayey and silty contaminated soils in slurry phase bioreactor over time is depicted in Fig. 2 and 3 , respectively. According to Fig. 2 and 3 concentration of 100 and $500 \mathrm{mg} \mathrm{L}^{-1}$ of phenanthrene in clayey soil reached to non detectable limit after 5 and 7 weeks, respectively. This condition was pretty different for silty soil, as in this case concentration of 100 and $500 \mathrm{mg} \mathrm{L}^{-1}$ of phenanthrene in silty soil reached to non detectable limit after 6 and 7 weeks, respectively. But concentration of $1000 \mathrm{mg} \mathrm{L}^{-1}$ both in clayey and silty soil samples has not met this limitation after 7 weeks.

Figures 4 and 5 shows the bacterial population growth changes during operation of slurry phase bioreactor over time in clayey and silty contaminated soils, respectively. Initial numeration of bacterial consortium in the first day of operation was determined at around $10^{9} \mathrm{CFU} \mathrm{g}$ in either clayey or silty soils.

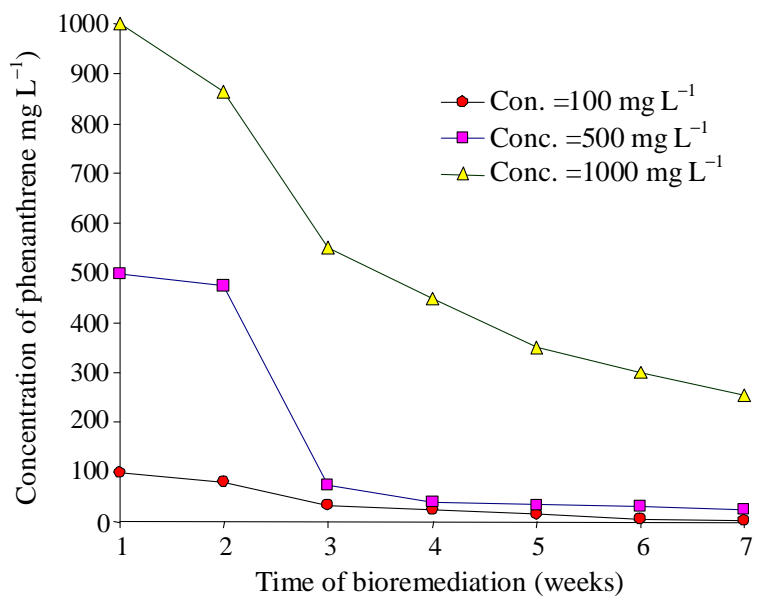

Fig. 3: Removal of phenanthrene in silty contaminated soil over time

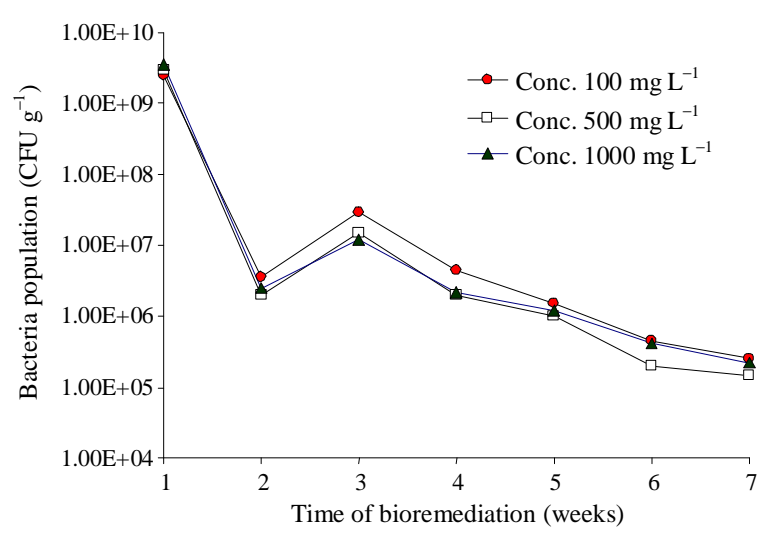

Fig. 4: Bacterial population changes in clayey contaminated soil over time

During the first week of bioreactor operation, bacterial population decreased to around $10^{6} \mathrm{CFU} \mathrm{g}^{-1}$ but in the end of second week it increased to around $10^{7} \mathrm{CFU} \mathrm{g}{ }^{-1}$, in both soil samples. After this time and until the end of bioreactor operation, bacterial population growth reduced constantly to less than $10^{6} \mathrm{CFU} \mathrm{g}^{-1}$ in the clayey soil sample (Fig. 4) and less than $10^{5} \mathrm{CFU} \mathrm{g}^{-1}$ in the silty soil sample (Fig. 5).

Average biotreatment of phenanthrene with different concentration in slurry bioreactor during 7 week bioremediation is shown in Fig. 6. With respect to Fig. 6 smaller concentration of phenanthrene has a high removal efficiency compared with higher concentration.

Average removal efficiency of phenanthrene in clayey and silty soil samples in slurry phase bioreactor versus time of biotreatment is shown in Fig. 7. 
Am. J. Environ. Sci., 5 (3): 223-229, 2009

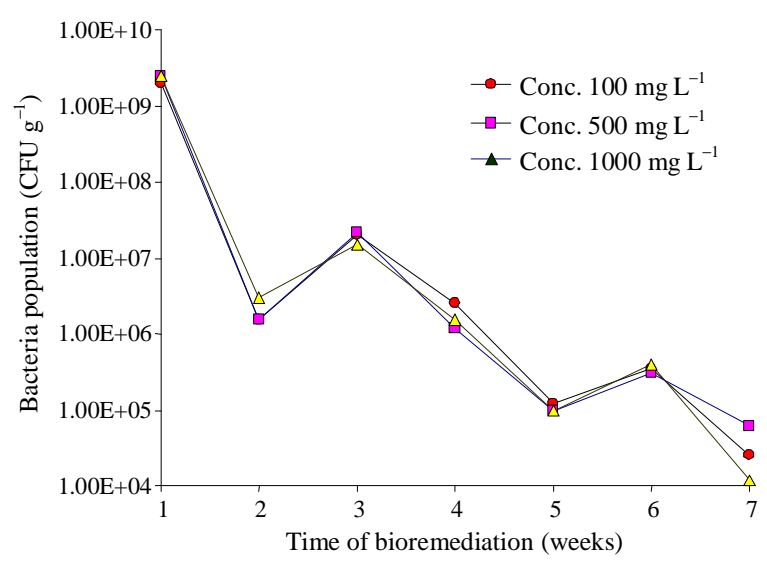

Fig. 5: Bacterial population changes in silty contaminated soil over time

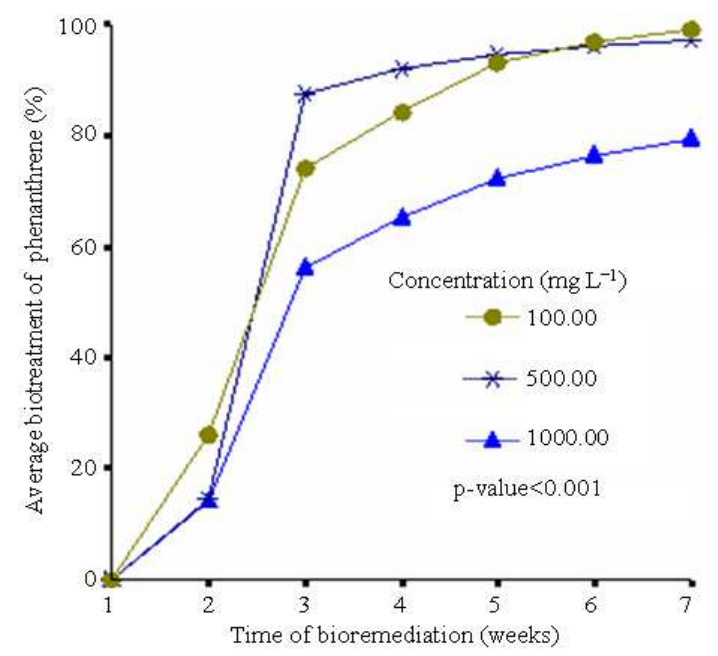

Fig. 6: Effect of initial concentration on average biodegrading of phenanthrene in slurry phase bioreactor over time

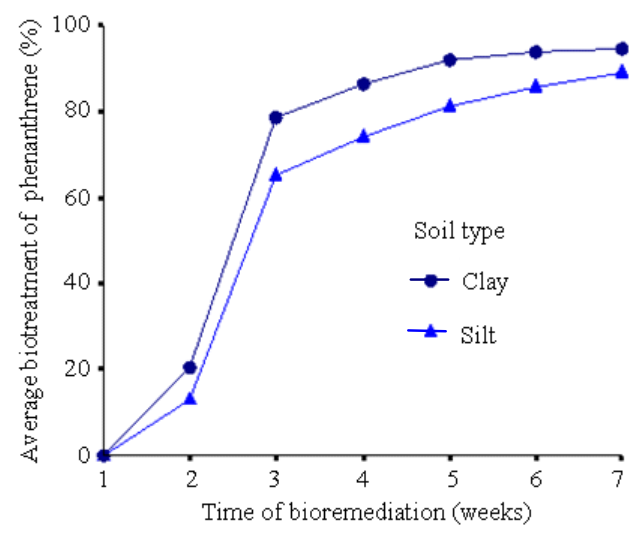

Fig. 7: Effect of soil type on average biodegrading of phenanthrene in slurry phase bioreactor over time
Table 2: Statistical result of concentration effect on removal efficiency of phenanthrene over time in slurry phase bioreactor

\begin{tabular}{llllll}
\hline Parameter & $\begin{array}{l}\text { Type III sum } \\
\text { of squares }\end{array}$ & df & $\begin{array}{c}\text { Mean } \\
\text { square }\end{array}$ & F & Significance \\
\hline $\begin{array}{l}\text { Phe. } \\
\text { concentration }\end{array}$ & 6250.062 & 2 & 3125.031 & 124.706 & $<0.001$ \\
\hline
\end{tabular}

\section{DISCUSSION}

Results from slurry bioreactor depicted that the overall biotreatment of lower concentrations of phenanthrene occurs faster than higher concentrations in both clayey and silty soils. As shown in Fig. 2, 3 and 6 , max removal of phenanthrene in different concentrations in slurry bioreactor occurs in the first 3 weeks of the bioremediation in clayey and silty soil samples, due to availability of phenanthrene in the dissolved condition and rapid growth of the bacterial population. Cookson ${ }^{[19]}$, demonstrated that the maximum removal efficiency (around 96\%) of PAH compounds in the slurry bioreactor take place after two weeks. In this research the types of soils have not specified. Using of a slurry phase bioreactor for remediation of PAH compounds, Jerger and $\mathrm{Pad}^{[20]}$ reached up to $93 \%$ removal efficiency.

Phenanthrene reduction over time of in slurry bioremediation in both clayey and silty soils during first 4 weeks of remediation complies of first order reaction model but after that until to end of week 7, removal of phenanthrene similar to zero order reaction model (Fig. 2 and 3).

In order to evaluation of concentration effect on removal efficiency of phenanthrene over time of remediation, General Linear Model with Repeated Measures analysis was applied. Table 2 shows result of this statistical analysis. According to this Table there is a significant relationship between different concentration in clayey and silty soils types with removal efficiency of phenanthrene in the slurry phase bioreactor ( $p$-value $<0.001)$.

In this research, average removal efficiency of phenanthrene in slurry bioreactor in clayey and silty soil samples during 45 days of biotreatment estimated up to $90 \%$ (Fig. 7). Slurry reactor studies have been used to evaluate the treatability of BTEX and PAH contaminated soil ${ }^{[21]}$, crude oil and refined petroleum products $^{[22]}$ and oil-contaminated sandy soil ${ }^{[23]}$. For example, Irvine et al. ${ }^{[24]}$ demonstrated the successful use of a soil slurry batch reactor for biotreatment of soils contaminated with petroleum hydrocarbons. They observed Total Petroleum Hydrocarbon (TPH) removal efficiencies greater than $96 \%$ in slurry reactors supplemented with nutrients ${ }^{[24]}$. 
Bacterial analyses using confirmative series tests and API 20E kit tests showed that the dominant bacterial populations in soil samples belonged to Pseudomonas, Serratia and Bacillus in clayey soil and Micrococcus, Serratia and Bacillus strains in silty soil, respectively. Based on the literatures review the most important bacteria in degrading the PAHs compounds in contaminated soils under aerobic conditions belong to Pseudomonas strains ${ }^{[1,3,25,26]}$. That is why, in our slurry bioreactor the removal efficiency of phenanthrene in clayey soil was a little more than silty soil samples over time.

Evaluation of the effect of different concentrations on removal efficiency of phenanthrene over time showed the control of $\mathrm{pH}$, nutrient amendment, aeration condition and well mixing of samples in the slurry bioreactor are important in order to achieve proper removal efficiencies. Therefore, this technology may be applied to remediation of small foot print oil contaminated soils in the case of urgency.

\section{REFERENCES}

1. Cerniglia, C.E., 1992. Biodegradation of polycyclic aromatic hydrocarbons. Biodegradation, 3: 351-368. DOI: 10.1007/BF00129093

2. Amellal, N., J.M. Portal and J. Berthelin, 2001. Effect of soil structure on bioavailability of polycyclic aromatic hydrocarbons within aggregates of a contaminated soil. Appl. Geochem., 16: 1611-1619. DOI: 10.1016/S08832927(01)00034-8

3. Wilson, S.C. and K.C. Jones, 1993. Bioremediation of soil contaminated with Polynuclear Aromatic Hydrocarbons (PAHs): A review. Environ. Pollut., 81: 229-249.

http://www.ncbi.nlm.nih.gov/pubmed/15091809

4. Samanta, S.K., A.K. Chakraborti and R.K. Jain, 1999. Degradation of Phenanthrene by different bacteria, Evidence for novel transformation sequences involving the formation of 1-naphthol. Applied Microbiol. Biotechnol., 53: 98-107. DOI: $10.1007 / \mathrm{s} 002530051621$

5. Sorkhoh, N.A., R.H. Al-Hasan, M. Khanafer and S.S. Radwan, 1995. Establishment of oil-degrading bacteria associated with cyanobacteria in oilpolluted soil. J. Applied Bacteriol., 78: 194-199. DOI: 10.1111/j.1365-2672.1995.tb02842.x

6. Norris, R.D., R.E. Hinchee, R. Brown, P.L. McCarty, L. Semprini, J.T. Wilson, D.H. Kampbell, M. Reinhard and C.H. Ward, 1994. Handbook of Bioremediation. 1st Edn., Lewis Publishers, Boca Raton, ISBN: 1566700744, pp: 257.
7. FRTR., 2008. Slurry phase biological treatment. http://www.frtr.gov/matrix2/section4/4-14.html

8. Woo, S.H., C.O. Jeon and J.M. Park, 2004. Phenanthrene biodegradation in soil slurry systems: Influence of salicylate and triton X-100. Korean J. Chem. Eng., 21: 412-418. DOI: 10.1007/BF02705429

9. BudHu Mini, 2002. Soil Mechanics and Foundation. 1st Edn., John Wiley and Sons, Inc., United States of America, pp: 522-553.

10. Kastner, M., M.J. Breuer and B. Mahro, 1998. Impact of inoculation protocols, salinity and $\mathrm{pH}$ on the degradation of Polycyclic Aromatic Hydrocarbons (PAHs) and survival of PAHdegrading bacteria introduced into soil. Applied Environ. Microbiol., 64: 359-362. http://aem.asm.org/cgi/content/abstract/64/1/359

11. APHA, AWWA, WEF, 2005. Standard Methods for the Examination of Water and Wastewater. 20th Edn., Washington DC., ISBN: 0-87553-235-7.

12. Bailey and Scott, 2000. Analytical Profile Index (API) 20E: Manual Procedure for Bacteriological Identification. 20th Edn., Washington DC., USA.

13. KNAUER, 2003. Sample preparation and HPLC analysis of PAHs in extracted soil samples. http://www.knauer.net/dwnld_fls/a_e_spe_pah_soil.pdf.

14. EPA Test Method, 1996. Polycyclic aromatic hydrocarbons (PAHs): Ultrasonic Extraction, Method 3550B and Method 8310.

15. US EPA., 2008. Wastes-hazardous waste-test methods. http://www.epa.gov/osw/hazard/testmethods/sw846/new _meth.htm

16. Arbabi, M., S. Nasseri, A.R. Medaghinia, S. Rezaie, K. Naddafi, G.H. Omrani and M. Yunesian, 2004. Survey on physical, chemical and microbiological characteristic of pah-contaminated soils in Iran. Iran. J. Environ. Health Sci. Eng., 1: 30-37. http://diglib.tums.ac.ir/pub/magmng/pdf/488.pdf

17. Sabrina, S., B. Luca, P. Gianniantonio, R. Loura and B. Meri, 2002. Polycyclic Aromatic Hydrocarbons (PAHs) slurry phase bioremediation of a Manufacturing Gas Plant (MGP) site Aged soil. Water Air Soil Pollut., 135: 219- 236. DOI: 10.1023/A:1014716502484

18. Jørgensen, K.S., J. Puustinen and A.M. Suortti, 2000. Bioremediation of petroleum hydrocarboncontaminated soil by composting in biopiles, Environ. Pollut., 107: 245-254. DOI: 10.1016/S0269-7491(99)00144-X

19. Cookson, J.J.J.R., 1995. Bioremediation Engineering Design and Application. 1st Edn., McGraw-Hill, Inc., New York, ISBN: 00-70126143, pp: 524. 
20. Woodhull, P.M. and D.E. Jerger, 2006. Bioremediation using a commercial slurry-phase biological treatment system: Site-specific applications and costs. Remediat. J., 4: 353-362. DOI: 10.1002/rem.3440040308

21. Mohan, V.S., T. Kisa, T. Ohkuma, R.A. Kanaly and Y. Shimizu, 2006. Bioremediation technologies for treatment of PAH-contaminated soil and strategies to enhance process efficiency. Rev. Environ. Sci. Biotechnol., 5: 347-374. DOI: 10.1007/s11157-006-0004-1

22. Huesemann, M.H., 1995. Predictive model for estimating the extent of petroleum hydrocarbon biodegradation in contaminated soils. Environ. Sci. Technol., 29:

7-18. http://cat.inist.fr/?aModele $=$ afficheN\&cpsidt $=3368193$

23. Puskas, K., N. AL-Awadhi, F. Abdullah and P. Literathy, 1995. Remediation of oil- contaminated sandy soil in a slurry reactor. Environ. Int., 21: 413-42. DOI: 10.1016/0160-4120(95)00035-J
24. Irvine, R.L., J.P. Earley, G.J. Kehrberger and B.T. Delaney, 1993. Bioremediation of soils contaminated with bis- (2-ethylhexyl) pthalate (BEHP) in a soil slurry-sequencing batch reactor. Environ. Prog., 12: 39-44. DOI: 10.1002/ep.670120108

25. Muller, J.G., P.J. Chapman and H.P. Pritchard, 1989. Action of a fluranthene- utilizing bacteria community on polycyclic aromatic hydrocarbon components of creosote. Applied Environ. Microbiol., 55: 3085-3090. http://aem.asm.org/cgi/content/abstract/55/12/3085

26. Livingston, R.J. and M.R. Islam, 1999. Laboratory modeling, field study and numerical simulation of bioremediation of petroleum contaminants, energy sources. Part A: Recov. Utilizat. Environ. Effects, 21: 113-129. DOI: 10.1080/00908319950014993 